\title{
CLINICAL STUDY OF EFFECT OF MUNDI TAILAM ON AKALAPALITHYAM WITH NASYAKARMA AND NASYA WITH PANAKARMA
}

\author{
Dr Devulapally Anuradha \\ Asst. Professor \& HOD, Dept. of Agadatantra, Dr. BRKR, G.A.C, Hyderabad, A.P., INDIA \\ *For Correspondence: Dr.D.Anuradha, M.D (Ay), Ph.D Scholar, Dr. NTR University of Health Sciences, Vijayawada, A.P, India, \\ Email: dranud@yahoo.com. \\ Received 04 Oct 2012; Review Completed 31 Oct 2012; Accepted 01 Nov 2012, Available online 15 Nov 2012
}

\begin{abstract}
:
Healthy hair is indication of healthy life. Akalapalithyam i.e. premature greying of hair is common burning problem particularly in youth resulting in cosmetic, mental and social issue. It is mainly due to pollution, modern life, malnutrition, physical \& mental stress and hereditary factors. Several products such as hair oils, dyes etc. are available in the market claiming cure for Akalapalithyam. Most of the dyes have side effects and complications. The need of the hour is to evolve a safe $\&$ effective cure for this growing problem. Administration of medicine through nose is nasya. This technique is useful in preventing as well as curing this disease. It expels disease causing agents. Nasa (Nose) is an entrance of Siras (Head). Therefore the nasya karma is the first choice of treatment to Sirokapala roga. The present clinical study is to evaluate the role of only Nasyakarma (Nasal Drops) and Nasyakarma with Panakarma (oil intake) of Munditailam on Premature greying (Akalapalithyam). In the present study 30 patients suffering from Akalapalithyam were randomly selected and divided into two groups. Group -A - 15 patients were given only Munditaila nasyam. Group-B-15 patients were given both nasyam \& Panam of Munditailam. The duration of treatment was 45 days. Response to the treatment was evaluated once in 15 days. The analysis is based on subjective improvement. Both the groups had good relief but group B showed significant improvement over group A.
\end{abstract}

Keywords: Munditailam, Premature greying (Akalapalithyam), Nasyakarma and Panakarma.

\section{INTRODUCTION:}

Nowadays the problem of premature greying (Akalapalithyam) is gradually increasing day by day in youth as well as adults ${ }^{1}$ due to irregular diet and change in life style.Presentday lifestyle of people is prone to more stress and strain resulting into many life style disorders. We can consider palityam is one among them. So there is a dire necessity to check this problem. Hence this studies taken for the research work. The vitiated Pitta dosha (hyper acidity) reaches Siras (head) and burns the hair follicle leading to premature greying. Excessive intake of bitter, sour \& chilly in food can cause anger, sorrow \& tiredness (Katu,Tikta,Ushnaahara sevena, Krooda, Soka andSrama).Smooth,oily,charming,shining are the characters of skin and hair of Twaksarapurusha that are desirable $2 \& .3$

In grey hair there is gradual dilution of pigment in the cavities, changing hair color from normal to white. The loss of pigment in the hair shafts is associated with a progressive loss of tyrosenase activity in the melanocytes thus leading to grey hair. ${ }^{4 \& 5}$ White hair commonly appears at temporal region and slowly involves the remaining area of the scalp over a period of time. Hair is rising from skin. ${ }^{6}$ Colour change of hair is due to the vitiation of kesabhoomi. ${ }^{7} \quad$ According to Ayurvedic acharyas Pittavikruti and Dustapratishyaya is the commonest cause for grey hair. ${ }^{8}$

According to Vagbhata "Urdwajtru Vikarshu Vesheshnam Nasyamithi Uchate".As Nose (nasa) is the entrance of siras, preferable treatment is Nasya karma. Mundi (Spaharanthus indicus) is abundantly \& cheaply available herb. Mundi tailam is also readily available drug and can be used safely. ${ }^{8 \& 9}$

\section{MATERIALS \& METHODS:}

Selection of Patients: 30 patients suffering from premature greying (Akalapalithyam) between the age group of 10-30 years were selected from the O.P of G.A.H, Erragadda, Hyderabad. These patients were subjected to detailed clinical examination \& investigations. They were randomly divided in two groups as $\mathrm{A}$ and $\mathrm{B}$.

'A' group: 15 registered patients were recommended only Nasyakarma (nasal drops inhalation) of Muditailam.

'B' group: 15 registered patients were recommended Naysakarma (Inhalation) as well as Panakarma (intake of oil with milk) of Munditailam.

\section{Dosage \& Duration of trial:}

A group: 3 to 6 drops of Muditailam as nasyakarma twice daily on empty stomach for 45 days.

B group: Along with nasyakarma (nasal drops) Panakarma (8-10 drops of Munditailam in a cup of lukewarm milk) is recommended twice daily on empty stomach for 45 days. $10 \& 11$

Clinical parameters: Before treatment a small area on the scalp is selected and shaved off. The grey and black hairs of the shaved off portion are counted. After treatment the number of grey hair \& black hair grown at the spot are again counted.

1) If more than $80 \%$ hair turns black it is considered aswell improved.

2) If $50 \%$ to $80 \%$ hair turns black it is considered partially improved. 
3) If below $20 \%$ hair turns black it is considered as- no improvement.

OBSERVATION \& RESULTS:

Table 1: The response in group ' $A$ ' patients

\begin{tabular}{|c|c|c|c|c|c|c|c|}
\hline \multirow{2}{*}{ S. No } & \multirow{2}{*}{ Response during } & \multicolumn{2}{|c|}{ Well improved } & \multicolumn{2}{c|}{ Partially improved } & \multicolumn{2}{c|}{ No improvement } \\
\cline { 3 - 8 } & & No. & $\mathbf{\%}$ & No. & $\mathbf{\%}$ & No. & $\mathbf{\%}$ \\
\hline 1. & $1-15$ days & 0 & 0 & 2 & 13.3 & 3 & 86.07 \\
\hline 2 & $16-30$ days & 0 & 0 & 5 & 33.3 & 10 & 66.7 \\
\hline 3 & 31-45 days & 2 & 13.3 & 6 & 40 & 7 & 46.7 \\
\hline
\end{tabular}

Table 2: The response in Group- B patients

\begin{tabular}{|c|c|c|c|c|c|c|c|}
\hline \multirow{2}{*}{ S. No } & \multirow{2}{*}{ Response during } & \multicolumn{2}{|c|}{ Well improved } & \multicolumn{2}{c|}{ Partially improved } & \multicolumn{2}{c|}{ No improvement } \\
\cline { 3 - 7 } & & No. & $\mathbf{\%}$ & No. & $\mathbf{\%}$ & No. & $\mathbf{\%}$ \\
\hline 1. & $1-15$ days & 0 & 0 & 3 & 20.0 & 12 & 80.0 \\
\hline 2 & $16-30$ days & 2 & 13.3 & 6 & 40.0 & 7 & 46.7 \\
\hline 3 & 31-45 days & 5 & 33.3 & 8 & 53.3 & 2 & 13.3 \\
\hline
\end{tabular}

Table 3: The response in group-A \& group-B patients put together

\begin{tabular}{|c|c|c|c|c|c|c|c|}
\hline \multirow{2}{*}{ S. No } & \multirow{2}{*}{ Response during } & \multicolumn{2}{|c|}{ Well improved } & \multicolumn{2}{c|}{ Partially improved } & \multicolumn{2}{c|}{ No improvement } \\
\cline { 3 - 7 } & & No. & $\mathbf{\%}$ & No. & $\mathbf{\%}$ & No. & $\mathbf{\%}$ \\
\hline 1. & $1-15$ days & 0 & 0 & 5 & 16.7 & 25 & 83.3 \\
\hline 2 & $16-30$ days & 2 & 6.6 & 11 & 36.7 & 17 & 56.7 \\
\hline 3 & 31-45 days & 7 & 23.3 & 14 & 46.7 & 9 & 30.0 \\
\hline
\end{tabular}

The above tables indicate that during 1-15 days there is only partial response to both types of treatments. After 15 days of treatment till 30 days 2 patients in group-B showed good improvement while partial improvement was seen in 11 patients from both the groups. At the end of the treatment 7 patients had excellent results while 14 showed partial response and 9 had no response.

\section{DISCUSSION:}

Out of 15 patients in group-A, $2(13.3 \%)$ had well improvement, 6(40\%) had partial improvement and there is no response in 7 cases after completion of the course. Whereas in group-B who were treated with Nasyakarma along with Panakarma 5 (33.3\%) had well improvement, 8 (53.3\%) had Partial improvement, and no response in two persons. On analysis of results from the above tables it is found that more patients in group-B had better results from the treatment when compared to group-A. It is also clear that the results were quicker in group-B patients. In this clinical trial 'Munditaila' pacifies pitta. Munditaila is absorbed through mucous membrane of the nose and reaches romakupas through shrungataka marma and cures the disease by dosha dushya vigatana. ${ }^{12}$

\section{CONCLUSION:}

Premature greying (Akalapalithyam) is a common cosmetic problem frequently seen in students as well as younger generation. ${ }^{13 \& 12}$ Nasyakarma is the first choice of treatment in palithyam cases. It is found from the study that Nasyakarma along with panakarma of Mundithailam is more effective in preventing as well as curing the problem. ${ }^{14 \& 8}$ No adverse effects were found of the treatment. As this study establishes the effectiveness of the above treatment it is advised that further continuing of the treatment on regular basis is essential to combat the ill-effects of pollution.

\section{ACKNOWLEDGMENT:}

I express my gratitude to my husband Sri.D.S.C.Kumar, M.Sc (Ag) for being helpful all through the study.

\section{BIBLIOGRAPHY:}

1. MAPIS August 1987.

2. Sri.JagadeshwarPrasadTripati-Chakradatta-Choukamba Sanskrit Samsthan, Varanasi-Charaka Indriyasthana5/4, Ch.vimanastana $8 / 99,100,104,107$

3. AmbikadattaSastry-SusruthaSamhita-Choukamba Sanskrit Samsthan, Varanasi-1981Susruta nidana-13/37.

4. Journal of investigalive dermatology -1973.

5. R.S.Satoshar Pharmacology part -II -812 .

6. Satyavathi pharmacology review 1983.

7. Ramaswami shastrulu - Susruta Samhita - Vavilla press, Madras-1954.

8. Vagbhata's: Astanga Hridyam (English) translated by Prof.K.R.Srikanth Murthy published by Krishna das Academy, Varanasi (2002 )uttarashana $3 / 9,4 / 44,36 / 32$.
9. Prof.R.H.Sing: Panchakarma Therapy Fist edition - Published by Chowkambha Sanskrit Series - Varanasi-1992.

10. Dearakanath.C-Digestion \&Metabolism-Baidyanath Ayurved Bhavan Pvt.Ltd.,Culcutta, $\mathrm{I}^{\text {st }}$ edition.

11. Agnivesha-Charak Samhita-Ramaswami .V\&Sons, Madras charaka chikista 26/90.

12. Ambikadatta Sastry-Susrutha Samhita-Choukamba Sanskrit Samsthan, Varanasi-1981.

13. Sidhdhartha N.Shah: API Text book of medicine $8^{\text {th }}$ edition (2008).

14. Bhavaprakasha-Bhavamistri 